\title{
Economic Modeling of the Behavior of Revival Churches in a Static Setting
}

\author{
Assoumou Ondo \\ CIREGED, Omar Bongo University, Libreville, Gabon \\ Email: assoumou7ondo@gmail.com
}

How to cite this paper: Ondo, A. (2020). Economic Modeling of the Behavior of Revival Churches in a Static Setting. Theoretical Economics Letters, 10, 1053-1072. https://doi.org/10.4236/tel.2020.105062

Received: May 31, 2020

Accepted: October 13, 2020

Published: October 16, 2020

Copyright (C) 2020 by author(s) and Scientific Research Publishing Inc. This work is licensed under the Creative Commons Attribution International License (CC BY 4.0).

http://creativecommons.org/licenses/by/4.0/

\begin{abstract}
This article is a contribution to the growing literature on the economics of religion. Indeed, to our knowledge, there is no study aimed at explaining the behavior of a revival church from a theoretical model. More precisely, we consider a household which, to maximize its usefulness, claims to be inhabited by the Holy Spirit, becomes a pastor and transforms its habitat into a church. He allocates his time in such a way as to attract and maintain faithful who, born again, offer their work in religious activity and/or make financial contributions. We show that the behavior of revival or awakened churches (Evangelical, Pentecostal, neo-Pentecostal, charismatic or prophetic) is fundamentally determined by the economic context: the level of employability, on the one hand, and the gap between the salary outside the church habitat and the internal salary fixed by the household-pastor to remunerate religious activity, on the other hand. In addition, we argue that in Africa, Revival Churches officiate in a context of unemployment and employ the maximum number of faithful in church activities and improvement. In return, they receive a remuneration lower than that of the labor market (case 4).
\end{abstract}

\section{Keywords}

Economics of Religion (Z12)

\section{Introduction}

The omnipresence and the continuous importance of religions in our societies, on the one hand, and the increase in the number of believers, on the other hand, give a renewed interest to the economic analysis of religion (Simmonot, 2008; Ekelund \& Hebert, 2009; Iyer, 2016; Obadia, 2017). Indeed, religious beliefs, practices and behaviors now play a role in the choice of homo-economicus (Becker, 1976; Azzi \& Ehrenberg, 1975). This new area of economics uses mi- 
croeconomic instruments to analyze the determinants of individual religiosity; the nature, emergence and evolution of the religious institution and the socio-economic impact of religion through the religion market (Berger, 1967; Azzi \& Ehrenberg, 1975; Anderson \& Tollison, 1992a; Ekelund et al., 1992; Iannaccone, 1995a and 1995b; Ekelund et al., 2002).

The economic analysis of religion reveals two main study grids: one that focuses on the demand for Religion, on the one hand, and that relates to the supply of Religion, on the other.

Regarding the demand for religious goods, Azzi and Ehrenberg (1975), followed by Ehrenberg (1977) and Sullivan (1985), consider that the consumption of religious goods does not result from irrational behavior. For this, they draw on the work of Becker (1976) on household production to show that individuals allocate their time and income among religious and secular products in order to maximize their usefulness of life (lifetime) and their usefulness after life (Stark et al., 1996; Iannaccone, 1998). Consumption from beyond is the main objective of religious participation. Such an allowance is characterized by uncertainty (Hull \& Bold, 1989; Iannaccone, 1995a and 1995b), because the promised rewards may never materialize, beliefs may prove to be false and sacrifices may be in vain. For these reasons, religion can also be understood through an approach in terms of religious human capital (Iannaccone, 1990). However, these different theories of the demand for religious property explain church attendance and affiliation, but they do not deal with the existence of churches per se.

With regard specifically to the supply of religious products, the economic approach suggests that religions behave like firms or businesses. Two main approaches are highlighted to explain the existence of churches. The first approach, defended by Anderson et al. (1992a and 1992b), Davidson and Ekelund (1997) and Ekelund et al. $(1989,1992,1996)$, argues that a church is a management company that maximizes profits. These authors analyze the actions of the Roman Catholic Church as a business aimed at monopolizing the religious market by regulating social norms (for example: sin and redemption), by eliminating competition (for example: the Crusades), or controlling wear and tear, exchange doctrines, innovations or the marriage market. In this context, another possibility is to consider a more selfish objective function: a church maximizes rent-seeking income by selling spiritual services at very high prices (Ekelund, Herbert, \& Tollison, 1992; Ekelund et al. 1996). The second approach, initiated by Iannaccone (1992 and 1998) and Zdeski and Zech (1992), suggests that a church maximizes the well-being of its members. This approach, discussed by Cassone and Marchese (1999), maintains that the church is a heterogeneous club which pursues enlargement within a set of constraints. It appears that members of the clergy are agents of the club and that the need to align the interests of members of the clergy with those of the church limits the growth of the church. In this vision, a church is then seen as a benevolent organization (in other words, who cares about the well-being of its members) but not their agents. It is therefore impor- 
tant, to understand the offer of religious products, to take into account the existence of stowaways and surveillance costs (Iannaccone, 1988, 1994a and 1994b; Montgomery, 1996a and 1996b), the presence of interest groups (Ekelund \& Hebert, 2009) and differentiation strategies (variety) of religious products (Barros \& Garoupaz, 2001; Stark \& Bainbridge, 1985 and 1987; Finke \& Stark, 1988 and 1992).

However, this literature does not take sufficient account of the development of the churches in developing countries. In particular, the implantation and the spread of "awakening" or "awakened" Churches (evangelical, pentecostal, neo-pentecostal, charismatic or prophetic) linked to the growing disappointment of the Christian faithful with regard to classical Christian structures (Catholic and Protestants), and the deployment of a critical view of the populations on the political and social management of their countries. The scale of the phenomenon is such that, according to the National Council of Evangelicals of France, the Evangelicals (including the Pentecostals) represent a quarter of the Christians in the world, that is to say 500 million people. On the African continent, this figure would rise to around 140 million (including 32 million in Nigeria and 15 million in the Democratic Republic of Congo). On the other hand, Fath and Mayrargue (2014) argue that there are 165 million revival church believers in Africa.

By definition, Soiron Fallut (2012) specifies that a "revival" Church is distinguished from the Catholic and Protestant Churches by four (4) essential criteria which relate to the practices and beliefs of the faithful:

1) Conversion: fundamental in the course of the believer, conversion is the consequence of a personal encounter with Jesus Christ. Baptism is a key moment in his life. This "new birth" implies a change of life and the new believer is then called a "born again";

2) Biblism: is the fact that the Bible is a source of authority in all aspects of the Christian's life. It constitutes the only normative reference in a direct relation to the text. In this, we can perceive the Protestant filiation within which the source of legitimacy is no longer the institution (or the Church) but the text;

3) Crucicentrism: the cross is the obligatory way and the place of salvation for humanity. Jesus having paid the price of the sin by the cross, the "debt" is settled and grace can come. So that only those accepting the work of the cross will be saved;

4) Activism: in this context, the proof of the existence of God must be manifested in the transformed life of the converts. The militant commitment is deployed in the difference with his old life, in the testimony of the convert and, more prosaically, in the sound system of the churches which tend to hear the biblical message as far as possible.

These "revival" churches are present mainly in South America (especially in Brazil) and in Sub-Saharan Africa (Liberia, Sierra-Leone, Benin, Togo, Nigeria, Gabon, Cameroon and Congo-Brazzaville), at the beginning of the 20th century. 
They consider that a person can ordain himself a Pastor, without needing the recognition of a religious authority or a diploma (Soiron Fallut, 2012); it is enough to claim to have received the Holy Spirit. Thus, certain places of housing and public places are often transformed, when the time comes, into a makeshift church. Understood that the faithful organize themselves to put in place all the amenities at the cost of all kinds of sacrifices (Soiron Fallut, 2012). Indeed, its "revival" churches offer more or less remunerated jobs to the members of their family, as well as to certain faithful. The faithful must therefore arbitrate between offering work in the church or outside, while offering financial contributions to the household-pastor for the improvement of its housing-church by the purchase of secular and religious goods. It then establishes a link between the revival church and the labor market that should be taken into account. As well as an absence of separation, between the Church and the habitat, often the source of many complaints against the "revival" churches.

This article is a contribution to the existing literature on the economics of religion in that it offers a theoretical modeling of the behavior of so-called "revival" churches determined by labor market conditions. More specifically, it is a model in which the household becomes a pastor (we will speak of the "household-pastor"), then transforms its habitat into a church. As for the faithful, "born new", they offer work there as well as financial contributions. In this structure, there is therefore no distinction between housing and the church (we will speak of "housing-church"). Consequently, the contributions collected from the faithful of the "revival" Church are used to finance their consumption of religious goods, secular goods and the hobbies of the household-pastor.

Aside from the interest in revival churches, the originality of this article lies in the modeling of the behavior of the "household-pastor" through a model of the "agricultural household" (Benjamin, 1992; Bardhan \& Udry, 1995; Singh, Squire, \& Strauss, 1986). Indeed, this type of model has the particularity of applying to any economic agent both producer and consumer of all or part of what it produces. We therefore define two (2) modules: 1) a religious activity module and 2) a consumption module. Such an approach differs from the "pure" producer, often used to analyze the behavior of classical religious structures.

The rest of the study is then structured as follows: Section 2 presents the model for determining the behavior of the revival church. Section 3 solves the model. Finally section 4 concludes.

\section{Presentation of the Model}

The model for determining the behavior of revival churches is articulated in two modules.

Indeed, we consider that the household becomes a Pastor, increases the number of faithful and the contributions (tithes and offerings) by committing resources (religious activity module). Then, get their satisfaction from the consumption of goods (including religious goods and secular goods) (consumption 
module). These two (2) modules coexist with a constraint linked to the use of household time.

1) Consumption Module

Unlike Anderson et al. (1992a and 1992b), Davidson and Ekelund (1997) and Ekelund et al. (1989, 1992 and 1996), then Iannaccone (1992 and 1998) and Zdeski and Zech (1992) who put forward the maximization of the profit or well-being of the members of the church, we first consider that the household-pastor maximizes satisfaction. Thus, the preferences of the household-pastor are described by a concave utility function, differentiable twice:

$$
U=u(c, k, l, \theta)
$$

where $c$ is the consumption of religious goods, $k$ the consumption of secular goods and $l$ is the consumption of leisure. In our formulation, $\theta$ represents a vector of demographic characteristics. We will assume that $\theta$ is exogenous at the choice of the household-pastor.

2) Religious activity module

We consider that the household-pastor develops a religious activity because it allows him to have the resources necessary to finance his consumption. The household-pastor receives a contribution $D$ proportional to the number of faithful $q$ in the church housing. If the "revival churches" do not always benefit from state financial support, these new temples develop independently, thanks to offerings and tithes from the faithful. These offerings are Sunday, but also "special" when it comes to supporting a project. The "tithe", the most important part withdrawn from the faithful, is monthly and corresponds, for all the faithful, to the tenth of his salary. To simplify the analysis, we consider that each follower gives a unique sum $\tau$. Thus, the total amount of the contributions of the faithful to the expansion of church housing is given by the following relationship:

$$
D=\tau q
$$

Household increases the number of faithful according to a technology (early childhood education, parental strengthening, selective membership, public declarations of commitment, promises of supernatural rewards and punishments, calls to history and sacred authority, etc.) represented by a concave and twice differentiable function:

$$
q=F(L ; A)
$$

With $A$ the area of church housing, assumed to be fixed and $L$ is the amount of work used in church housing. It is assumed that the work used comes from two sources: the family of the household-pastor $\left(L^{f}\right)$ or a faithful $\left(L^{b}\right)$, all «born again»:

$$
L=L^{f}+L^{b}
$$

We consider that there is a link between religiosity (the time of attendance at the Church) and the job market. More precisely, religiosity dampens the impact of unemployment on the satisfaction of the faithful's life (Lechner and Leopold, 
2015). Unemployment not only leads to loss of income, but is also a powerful stressor (Jahoda et al., 1971), with an impact on health, well-being and related outcomes (McKee-Ryan et al., 2005; Paul \& Moser, 2009). Thus, religious attendance $L^{b}$ improves the psychological resources which help to cope with unemployment, such as personal efficiency, optimism, a sense and a purpose of life, which are not linked to material success. As a result, the faithful are often led to devote time $L^{b}$ to religious service.

The «born again» is perceived as inhabited by the Holy Spirit who reveals himself through a set of religious services which are: 1) glossolalia (ability to speak in language), 2) the faculty of healing divine (through the laying on of hands) and 3) the possibility of delivering prophecies. He must also spread the word of God and will be saved when Jesus comes back down to Earth (Soiron Fallut, 2012). The faithful «born again» takes part in the organization of the «house-church» by occupying various functions such as: cashier, secretary, cleaning lady, driver, musician, etc.

It is assumed that there is a labor market and that the allocation of working time outside the house-church $L^{o}$ earns remuneration $w_{o}$ (competitive market wage rate). On the other hand, using a faithful $L^{b}$ to carry out certain activities in house-church costs $w_{e}$.

With:

$$
w_{o} \geq w_{e}
$$

Indeed, like Iannaccone (1998), we consider that the faithful who devote their time to the activities of «house-church» hope mainly to be $L^{o} \leq H$ benefit from utility after life. They therefore accept a salary $w_{e}$, lower than that of the market $w_{o}$, fixed by the household-pastor. It is assumed that family work and work of the faithful are substitutable, but that a unit of work of the faithful is worth $\alpha$ unit of family work, with $\alpha>1$. In other words, the devotee has a greater ability to attract other believers into church housing than family members.

Thus, to obtain one hour of family work, one must call $1 / \alpha$ hours of the faithful's work, at the cost of $w$ per hour. As a result, the family work hour costs $w / \alpha=w^{e f f}\left(\equiv w_{e}\right)$.

The total working time $L$, measured in effective family work equivalent units, gives:

$$
L_{e}^{f}=L^{f}+\alpha L^{b}
$$

In this model, the only variable factor of production is therefore work.

3) Time constraint

The household has a total time endowment of $T(\theta)$, which is a function of the characteristics $\theta$. Having assumed that $\theta$ being exogenous, then $T$ is fixed. It is assumed that the household can allocate this endowment between three destinations: working in «house-church» $\left(L^{f}\right)$, working outside «house-church» $\left(L^{o}\right)$ or in the form of leisure $(I)$.

$$
L^{f}+L^{o}+l=T(\theta)
$$


However, we assume that there is involuntary unemployment in the labor market. Indeed, we consider that one of the concerns of the faithful and of the household-pastor of revival churches concerns the search for employment. In this case, the household-pastor faces a constraint in the supply of its labor outside the «house-church». We consider that the labor market allows the household-pastor to sell at most $\mathrm{H}$ hours of his work:

$$
L^{o} \leq H
$$

4) Household-pastor program

Under the conditions described, it is assumed that the household-pastor maximizes its utility given by (1) under the constraints given by (3), (4), (5), (6), (7) and (8). It is assumed that the household has an exogenous income $y$ (for example from subsidies received from the State). Furthermore, we consider that the prices of religious and secular goods are respectively $p_{c}$ and $p_{k}$.

The household-pastor model (9) is then written:

$$
\begin{aligned}
& \text { Max. } u(c, k, l, \theta) \\
& \text { s.c }\left\{\begin{array}{l}
p_{c} c+p_{k} k=D-w_{e} \alpha L^{b}+w_{o} L^{o}+y \\
D=\tau q \\
q=F\left(L_{e}^{f} ; A\right) \\
T(\theta)=L^{f}+L^{o}+l \\
L_{e}^{f}=L^{f}+\alpha L^{b} \\
w_{o} \geq w_{e} \\
L^{o} \leq H \\
L^{o} \leq H
\end{array}\right.
\end{aligned}
$$

The first constraint simply indicates that the household-pastor finances its consumption of religious $c$ and secular goods $k$ by using the income from religious activity $D$, the product of labor hired out of the «house-church», $w_{o} L^{o}$ its exogenous income y and by deducting the labor cost of the faithful «born again» $w_{e} \alpha L^{b}$.

\section{Model Resolution}

By using the first two identities, the constraint becomes:

$$
p_{c} c+p_{k} k=\tau F\left(L_{e}^{f} ; A\right)-w_{e} \alpha L^{b}+w_{o} L^{o}+y
$$

In accordance with the work of Lechner and Leopold (2015), the religiosity of the household-pastor and the faithful depends on employability on the labor market. Thus, taking into account the constraint (8) reveals two main cases: the first case 1) considers that the household-pastor wishes to offer only a quantity of work $L^{o}$ below the maximum threshold $H$. This configuration is assimilated to voluntary unemployment. The second case 2) suggests, for its part, that the household-pastor wishes to offer more work outside the church housing, but is limited to $H$. This context is assimilated to a situation of involuntary unemployment. 
Let us first consider the case of voluntary unemployment of the pastoral household.

Case 1: $L^{o}<H$ (voluntary unemployment).

By integrating the time allocation of the household-pastor, it is written as follows:

$$
p_{c} c+p_{k} k=\psi\left(L_{e}^{f} ; L^{f} ; L^{b} ; A ; w_{o} ; w_{e} ; \tau ; \alpha\right)+w_{o} T(\theta)+y \equiv R
$$

With:

$$
\psi\left(L_{e}^{f} ; L^{f} ; L^{b} ; A ; w_{o} ; w_{e} ; \tau ; \alpha\right)=\tau F\left(L_{e}^{f} ; A\right)-w_{o}\left[L^{f}+\left(w_{e} / w_{o}\right) \alpha L^{b}\right]
$$

Who says that the consumption of goods (secular and religious) and leisure is equal to the overall income of the householder, $R$. This total income comprises three components:

- The benefit of non-maximized religious activity: $\psi\left(L_{e}^{f} ; L^{f} ; L^{b} ; A ; w_{o} ; w_{e} ; \tau ; \alpha\right)$;

- Valuation of the time allocation of the household-pastor: $w_{o} T(\theta)$, indicating the opportunity cost of the time of the household-pastor;

- The income of the householder from exogenous sources, $y$.

The household must choose the levels of $c, k$ and $l$ for:

$$
\begin{aligned}
& \text { Max. } u(c, k, l, \theta) \\
& \text { s.c }\left\{\begin{array}{l}
p_{c} c+p_{k} k+w_{o} l=R \\
L_{e}^{f}=L^{f}+\alpha L \\
w_{o} \geq w_{e}
\end{array}\right.
\end{aligned}
$$

In this entry, income $R$ includes the three components discussed above. It follows that the value of $u($.$) can increase as long as R$ can increase. For $u($.$) to$ be at its maximum, $R$ must also be at its maximum level. Now, two of the components of $R$ are fixed (the exogenous income $y$ and the value of time $w_{o} T(\theta)$ ). $R$ will reach its maximum if $\psi\left(L_{e}^{f} ; L^{f} ; L^{b} ; A ; w_{o} ; w_{e} ; \tau ; \alpha\right)$ is maximum.

In a situation of voluntary unemployment, the allocation of the working time of the household-pastor in the church housing $L^{f}$ depends on the remuneration he receives there $w_{e}$, compared to the salary $w_{o}$ which he would have received out of the church habitat. The comparison of the two wage rates (constraint (5)) allows us to identify two alternatives to this first case. While the first alternative is based on the principle that the pastoralist household will allow an internal wage rate $w_{e}$ equal to $w_{o}$, the second alternative suggests that the pastoralist household will set an internal wage rate $w_{e}$ lower than $w_{o}$.

Alternative 1: $w_{o}=w_{e}$

In this alternative, the household-pastor pays each hour of work (family or that of the faithful) in church housing at the hourly market wage $w_{o}$.

The profit of religious activity is written:

$$
\psi\left(L_{e}^{f} ; A ; w_{o} ; \tau ; \alpha\right)=\tau F\left(L_{e}^{f} ; A\right)-w_{o} L_{e}^{f}
$$

To maximize the profit from religious activity, simply choose $L_{e}^{f}$ such that: 


$$
\partial \psi / \partial L_{e}^{f}=0
$$

This requires that: $F^{\prime}\left(L_{e}^{f} ; A\right)=w_{o} / \tau$, the standard condition that at optimum the «house-church» chooses the amount of work in the church habitat (the glossolalia, the faculty of divine healing, the possibility of delivering prophecies, of occupying the functions of cashier, secretary, cleaning lady, driver, musician, etc.) so as to equalize the value of the marginal faithful converted at the price of the postman. With $L_{e}^{f^{*}}$, the optimal amount of work in church housing which maximizes the number of faithful «born again».

Given the optimal value $L_{e}^{f^{*}}\left(A ; w_{o} ; \tau ; \alpha\right)$ of $L_{e}^{f}$, we deduce the maximum number of faithful in the «house-church» $q^{*}=F\left(L_{e}^{f^{*}} ; A\right)$, the maximum amount of contributions $D^{*}=\tau q^{*}$ and the maximum benefit of the pastor-pastor in the religious activity, is:

$$
\psi\left(L_{e}^{f^{*}} ; A ; w_{o} ; \tau ; \alpha\right)=D^{*}-w_{o} L_{e}^{f^{*}} \equiv \Pi\left(A ; w_{o} ; \tau ; \alpha\right)
$$

where $\Pi\left(A ; w_{o} ; \tau ; \alpha\right)$ is the household profit function.

We deduct the maximized overall income of the householder:

$$
R^{*}=\Pi\left(A ; w_{o} ; \tau ; \alpha\right)+w_{o} T(\theta)+y
$$

As a result, the problem of the household-pastor takes the following classic form:

$$
\begin{array}{ll}
\text { Max. } & u(c, k, l, \theta) \\
\text { s.c } & p_{c} c+p_{k} k+w_{o} l=R^{*}
\end{array}
$$

This is the classic consumer problem, the solution of which is given by the Marshallian demand functions:

The first-order conditions give the following results:

$$
\begin{aligned}
& c^{*}=c\left(w_{o} ; p_{c} ; p_{k} ; \tau ; \alpha ; \Pi+w_{o} T(\theta)+y ; \theta\right) ; \\
& k^{*}=k\left(w_{o} ; p_{c} ; p_{k} ; \tau ; \alpha ; \Pi+w_{o} T(\theta)+y ; \theta\right) ; \\
& l^{*}=l\left(w_{o} ; p_{c} ; p_{k} ; \tau ; \alpha ; \Pi+w_{o} T(\theta)+y ; \theta\right) ;
\end{aligned}
$$

The supply function of the householder is deduced from this:

$$
L^{s}\left(w_{o} ; p_{c} ; p_{k} ; \tau ; \alpha ; \Pi+w_{o} T(\theta)+y ; \theta\right)=L^{o}+L^{f}=T(\theta)-l^{*}
$$

Result 1: When $L^{o}<H$ and $w_{o}=w_{e}$, the module of religious activity is not influenced by the preferences of the household-pastor. Given the performance differential, the latter determines the amount of labor $L_{e}^{f^{*}}$ that maximizes its profit in religious activity, by preferring the employment of the faithful in the «house-church» for a rate of salary $w_{o}$. This profit, supplemented by $w_{o} L^{o}$ resources from work offered outside the church home and transfers received $y$, increases his overall income $R^{*}$ which allows him to consume the quantities of secular property $k$, religious property $c$ and leisure $I$ maximizing one's individual well-being.

In this result 1, apart from the payment of contributions, the faithful spend 
their working time in church housing and receive in return a salary $w_{e}$ identical to that which they would have obtained outside «house-church». The faithful being more efficient in religious activities, they favor the increase of total contributions. To maximize their overall income, the household-pastor can therefore devote more time to activities outside «house-church», which allows them to obtain additional income $w_{o} L^{o}$.

However, this result 1 does not fully maximize the income $R^{*}$ and the satisfaction of the household-pastor who, based on the beliefs of the faithful, would benefit from fixing an internal salary $w_{e}$ lower than that of the market $w_{o}$.

Alternative 2: $w_{o}>w_{e}$

In this alternative, the salary outside church housing is higher than the compensation paid in church housing.

The objective of the household-pastor is to:

$$
\begin{aligned}
& \text { Max. } u(c, k, l, \theta) \\
& \text { s.c } \quad p_{c} c+p_{k} k+w_{o} l=\psi\left(L^{f} ; L^{b} ; w_{o} ; w_{e} ; \tau ; \alpha\right)+w_{o} T(\theta)+y \equiv R
\end{aligned}
$$

With:

$$
\psi\left(L^{f} ; L^{b} ; A ; w_{o} ; w_{e} ; \tau ; \alpha\right)=\tau F\left(L^{f} ; L^{b} ; A\right)-w_{o}\left[L^{f}+\left(w_{e} / w_{o}\right) \alpha L^{b}\right]
$$

The determination of $L^{f}$ and $L^{b}$ is carried out by solving the following system:

$$
\left\{\begin{array}{l}
\partial \psi / \partial L^{f}=0 \\
\partial \psi / \partial L^{b}=0
\end{array}\right.
$$

Levels of $L^{f^{*}}$ and $L^{b^{*}}$ under the following conditions:

$$
\left\{\begin{array}{l}
F_{L^{f}}^{\prime}\left(L^{f^{*}} ; L^{b^{*}} ; A\right)=w_{o} / \tau \\
F_{L^{b}}^{\prime}\left(L^{f^{*}} ; L^{b^{*}} ; A\right)=\alpha\left(w_{e} / \tau\right)
\end{array}\right.
$$

Since: $w_{o}>w_{e}$ and $\alpha>1$, we obtain:

$$
L^{f^{*}}\left(A ; w_{e} ; w_{o} ; \tau ; \alpha\right) \text { and } L^{b^{*}}\left(A ; w_{e} ; w_{o} ; \tau ; \alpha\right)
$$

To simplify, we consider that the faithful hired in the «house-church» are paid in such a way that $w_{o}>\alpha w_{e}$, which allows you to have:

$$
\begin{gathered}
F_{L^{f}}^{\prime}\left(L^{f^{*}} ; L^{b^{*}} ; A\right)>F_{L^{b}}^{\prime}\left(L^{f^{*}} ; L^{b^{*}} ; A\right) \\
\text { And so: } L^{f^{*}}<L^{b^{*}}
\end{gathered}
$$

By integrating $L^{f^{*}}\left(A ; w_{e} ; w_{o} ; \tau ; \alpha\right)$ and $L^{b^{*}}\left(A ; w_{e} ; w_{o} ; \tau ; \alpha\right)$ the optimal amounts of work in the habitat are church that maximize the number of faithful, deduces the maximum number of faithful in the «house-church» $q^{*}=F\left(L^{f^{*}} ; L^{b^{*}} ; A\right)$, as well as the maximum number of contributions $D^{*}=\tau q^{*}$ and maximum benefit of the household-pastor in the religious activity, namely:

$$
\begin{aligned}
\psi\left(L^{f^{*}} ; L^{b^{*}} ; A ; w_{o} ; w_{e} ; \tau ; \alpha\right) & =D^{*}-w\left[L^{f^{*}}+\left(w_{e} / w_{o}\right) \alpha L^{b^{*}}\right] \\
& \equiv \Pi\left(A ; w_{e} ; w_{o} ; \tau ; \alpha\right)
\end{aligned}
$$


where $\Pi\left(A ; w_{e} ; w_{o} ; \tau ; \alpha\right)$ is the profit function of the household-pastor.

We deduce the maximum overall income of the household-pastor:

$$
R^{*}=\Pi\left(A ; w_{e} ; w_{o} ; \tau ; \alpha\right)+w_{o} T(\theta)+y
$$

As a result, the household-pastor problem takes the following classic form:

$$
\begin{aligned}
& \text { Max. } u(c, k, l, \theta) \\
& \text { s.c } \quad p_{c} c+p_{k} k+w_{o} l=R^{*}
\end{aligned}
$$

This is the classic consumer problem, the solution of which is given by the Marshallian demand functions:

$$
\begin{aligned}
& c^{*}=c\left(w_{e} ; w_{o} ; p_{c} ; p_{k} ; \tau ; \alpha ; \Pi+w_{o} T(\theta)+y ; \theta\right) ; \\
& k^{*}=k\left(w_{e} ; w_{o} ; p_{c} ; p_{k} ; \tau ; \alpha ; \Pi+w_{o} T(\theta)+y ; \theta\right) ; \\
& l^{*}=l\left(w_{e} ; w_{o} ; p_{c} ; p_{k} ; \tau ; \alpha ; \Pi+w_{o} T(\theta)+y ; \theta\right) ;
\end{aligned}
$$

We deduce the job supply function of the household-pastor:

$$
L^{s}\left(w_{e} ; w_{o} ; p_{c} ; p_{k} ; \tau ; \alpha ; \Pi+w_{o} T(\theta)+y ; \theta\right)=L^{o}+L^{f}=T(\theta)-l^{*}
$$

Result 2: When $L^{o}<H$ and that $w_{o}>w_{e}$, the module of religious activity is influenced by the preferences of the household-pastor. In order to consume more religious, secular and leisure goods, the household-pastor maximizes the profit of religious activity by employing the majority of the faithful in «house-church» at the price $w_{e}$. In addition, he supplements his income by directing a large part of working time outside the «house-church», which allows him to benefit from higher remuneration $w_{o}$.

Result 2 is such that, apart from the payment of contributions, the faithful spend their working time in «house-church», but receive in return a salary $w_{e}$ lower than that which they would have obtained outside «house-church». The faithful accept the wage level $w_{e}$ because of the relationship they establish between the job offer $\alpha L^{b}$ and the satisfaction of serving God. However, they may be tempted to offer their labor power outside of church housing in order to be paid $w_{o}$. In fact, every hour spent in church housing costs him $\left(w_{o}-w_{e}\right)$. Thus, the number of faithful "born again" increases, which increases the total contribution $D^{*}$. In addition, the household-pastor benefits from the higher salary $w_{o}$ offered by activities outside housing-church. The income $R^{*}$, thus obtained, allows the household-pastor to increase its consumption of secular, religious and leisure goods.

After presenting these first two results, let us now consider the case of involuntary unemployment of the pastoral household.

Case 2: $L^{o}=H \quad$ (involuntary unemployment).

In this case, the household-pastor would like to offer more $H$ hours on the job market, but can only offer $H$. We are in a situation of surplus labor.

By rewriting, the household-pastor constraint becomes:

$$
p_{c} c+p_{k} k=\tau F\left(T(\theta)+\alpha L^{b}-H-l ; A\right)-w_{e} \alpha L^{b}+w_{o} H+y
$$


With: $w_{o} \geq w_{e}$

Or:

$$
p_{c} c+p_{k} k=\psi\left(L^{b} ; l ; A ; w_{e} ; \tau ; \alpha\right)+w_{o} H+y \equiv R
$$

With:

$$
\psi\left(L^{b} ; l ; A ; w_{e} ; \tau ; \alpha\right)=\tau F\left(T(\theta)+\alpha L^{b}-H-l ; A\right)-w_{e} \alpha L^{b}
$$

As in case 1, taking the constraint (6) into account allows two alternatives to this second case to emerge:

Alternative 3: $w_{o}=w_{e}$

In this alternative, the profit of religious activity is written:

$$
\psi\left(L^{b} ; l ; A ; w_{o} ; \tau ; \alpha\right)=\tau F\left(T(\theta)+\alpha L^{b}-H-l ; A\right)-w_{o} \alpha L^{b}
$$

The household-pastor determine the number of hours of leisurel, the consumption levels of goods (religious and secular) $c$ and $k$, as well as the number of faithful hired in the «house-church» $L^{b}$ by solving the following system:

$$
\begin{aligned}
& \text { Max. } u(c, k, l, \theta) \\
& \text { s.c } p_{c} c+p_{k} k=\tau F\left(T(\theta)+\alpha L^{b}-H-l ; A\right)+w_{o}\left(H-\alpha L^{b}\right)+y \equiv R
\end{aligned}
$$

We consider, to simplify, in this context that the number of faithful offering their work in the «house-church» is fixed exogenously by the household-pastor, so as to increase their income, $R$. Note that $R$ is all the more higher than $H-\alpha L^{b}$ is large. In other words, let $L^{b}$ is weak for $H$ given. Therefore, it is reasonable to consider that the household-pastor will be tempted to choose $L^{b}=0$. All the work in the «house-church» will be entrusted to the members of his family. In this context, we solve the following program:

$$
\begin{aligned}
& \text { Max. } u(c, k, l, \theta) \\
& \text { s.c } p_{c} c+p_{k} k=\tau F\left(T(\theta)+\alpha L^{b}-H-l ; A\right)+w_{o} H+y \equiv R
\end{aligned}
$$

By writing the first order conditions for this problem, we get:

$$
\left\{\begin{array}{l}
u_{c}^{\prime}-\lambda p_{c}=0 \\
u_{k}^{\prime}-\lambda p_{k}=0 \\
u_{l}^{\prime}-\lambda F^{\prime}(T(\theta)-H-l ; A)=0 \\
\tau F(T(\theta)-H-l ; A)+w_{o} H+y-p_{c} c-p_{k} k=0
\end{array}\right.
$$

With $\lambda$, the Lagrange multiplier.

The following condition is obtained:

$$
\left\{\begin{array}{l}
u_{l}^{\prime} / u_{c}^{\prime}=F_{l}^{\prime}(T(\theta)-H-l ; A) / p_{c} \\
u_{l}^{\prime} / u_{k}^{\prime}=F_{l}^{\prime}(T(\theta)-H-l ; A) / p_{k} \\
u_{c}^{\prime} / u_{k}^{\prime}=p_{c} / p_{k}
\end{array}\right.
$$

We determine the values at equilibrium:

$$
c^{*}=c\left(A ; w_{o} ; p_{c} ; p_{k} ; \tau ; H ; y ; \theta\right)
$$




$$
\begin{aligned}
& k^{*}=k\left(A ; w_{o} ; p_{c} ; p_{k} ; \tau ; H ; y ; \theta\right) ; \\
& l^{*}=l\left(A ; w_{o} ; p_{c} ; p_{k} ; \tau ; H ; y ; \theta\right) ;
\end{aligned}
$$

Thus, the balance of the household-pastor now implies the equality between the marginal rate of substitution between consumption (of religious and secular goods) and leisure and the marginal product of work in the «house-church». In other words, a combination of preferences and technological parameters defines balance.

Result 3: When $L^{o}=H$ and $w_{o}=w_{e}$, the module of religious activity is influenced by the preferences of the household-pastor. In order to maximize his well-being through the consumption of religious, secular and leisure goods, he directs a maximum amount of $H$ of working time outside the «house-church», which allows him to receive remuneration $w_{o} H$. In addition, the household-pastor computes his income by using only his labor in «house-church» at the price $w_{o}$. The faithful, on the other hand, intervene only in the contributions $\tau$ paid in «house-church».

In this result 3, the household-pastor wishes to offer more hours of work outside the «house-church», but is limited to $H$ paid hour at $w_{o}$. The salaries being identical, he then allocates the rest of his working time within the «house-church», substituting it as much as possible for the work offered by the faithful. In this context, the faithful only participate in the payment of contributions in the «house-church».

Alternative 4: $w_{o}>w_{e}$

The constraint of the household-pastor is written:

$$
p_{c} c+p_{k} k=\tau F\left(T(\theta)+\alpha L^{b}-H-l ; A\right)+w_{o}\left[H-\left(w_{e} / w_{o}\right) \alpha L^{b}\right]+y \equiv R
$$

With: $w_{o}>w_{e}$

The household-pastor determine the number of hours of leisure $l$, the consumption levels of goods (religious and secular) $c$ and $k$, as well as the number of faithful hired in the «house-church» $L^{b}$ by solving the following system:

Max. $u(c, k, l, \theta)$

s.c $p_{c} c+p_{k} k=\tau F\left(T(\theta)+\alpha L^{b}-H-l ; A\right)+w_{o}\left[H-\left(w_{e} / w_{o}\right) \alpha L^{b}\right]+y \equiv R$

With: $w_{o}>w_{e}$

Given that: $w_{o}>w_{e}$ and $\alpha>1$, with: $w_{o}>\alpha w_{e}$, we consider, for simplicity, that the number of faithful offering their work $L^{b}$ in «house-church» and their remuneration $w_{e}$ are fixed exogenously by the household-pastor, so as to increase income, $R$. Note that $R$ is all the higher as $H-\left(w_{e} / w_{o}\right) \alpha L^{b}$ and $T(\theta)+\alpha L^{b}-H-l$ are great. There are two possibilities for the household-pastor:

Reduce $L^{b}$ for $w_{e}$ and $H$ fixed. This approach has the advantage of minimizing the cost $w_{o}\left[H-\left(w_{e} / w_{o}\right) \alpha L^{b}\right]$, on the one hand, and the disadvantage of also reducing the working time $T(\theta)+\alpha L^{b}-H-l$ used to increase the 
number of faithful in the "house-church», on the other hand. Considering the extreme case where the household-pastor chooses $L^{b}=0$; the latter decides to only employ his family in religious activity;

The program is the same as in alternative 3 . It is written:

$$
\begin{aligned}
& \text { Max. } u(c, k, l, \theta) \\
& \text { s.c } p_{c} c+p_{k} k=\tau F\left(T(\theta)+\alpha L^{b}-H-l ; A\right)+w_{o} H+y \equiv R
\end{aligned}
$$

With: $w_{o}>w_{e}$

Reduce $w_{e}$ for $L^{b}$ and $H$ fixed. This approach has the double advantage of minimizing the cost $H-\left(w_{e} / w_{o}\right) \alpha L^{b}$, on the one hand, and of increasing the working time $T(\theta)+\alpha L^{b}-H-l$ used to increase the number of faithful $q$ in the «house-church», on the other hand. It is then possible to consider the case $w_{e}=0$ where the household-pastor does not remunerate the faithful who offer their work $\alpha L^{b}$ in «house-church». In this context, the household-pastor will be tempted to increase the number of faithful in the church habitat, while taking into account the available space $A$. Considering that the area of the church habitat $A$ only allows a maximum number of faithful fixed at $M$, it is then possible to set: $L^{b}=M$

The program is then written as follows:

$$
\begin{aligned}
& \text { Max. } u(c, k, l, \theta) \\
& \text { s.c } p_{c} c+p_{k} k=\tau F(T(\theta)+\alpha M-H-l ; A)+w_{o} H+y \equiv R
\end{aligned}
$$

With: $w_{o}>0$

By writing the first conditions of this problem, we obtain:

$$
\left\{\begin{array}{l}
u_{c}^{\prime}-\lambda p_{c}=0 \\
u_{k}^{\prime}-\lambda p_{k}=0 \\
u_{l}^{\prime}-\lambda F^{\prime}(T(\theta)+\alpha M-H-l ; A)=0 \\
\lambda F_{L^{\prime}}^{\prime}(T(\theta)+\alpha M-H-l ; A)=0 \\
\tau F(T(\theta)+\alpha M-H-l ; A)+w_{o} H+y-p_{c} c-p_{k} k=0
\end{array}\right.
$$

With $\lambda$, the Lagrange multiplier.

The following condition is obtained:

$$
\left\{\begin{array}{l}
u_{l}^{\prime} / u_{c}^{\prime}=F_{l}^{\prime}(T(\theta)+\alpha M-H-l ; A) / p_{c} \\
u_{l}^{\prime} / u_{k}^{\prime}=F_{l}^{\prime}(T(\theta)+\alpha M-H-l ; A) / p_{k} \\
u_{c}^{\prime} / u_{k}^{\prime}=p_{c} / p_{k}
\end{array}\right.
$$

We determine the values at equilibrium:

$$
\begin{aligned}
& c^{*}=c\left(A ; w_{o} ; p_{c} ; p_{k} ; \tau ; M ; H ; y ; \theta\right) ; \\
& k^{*}=k\left(A ; w_{o} ; p_{c} ; p_{k} ; \tau ; M ; H ; y ; \theta\right) ; \\
& l^{*}=l\left(A ; w_{o} ; p_{c} ; p_{k} ; \tau ; M ; H ; y ; \theta\right) ;
\end{aligned}
$$

Thus, the balance of the household-pastor now implies equality between the 
marginal rate of substitution between consumption (of religious and secular goods) and leisure and the marginal product of work in «house-church». In other words, a combination of preferences and technological parameters defines the balance.

Result 4: When $L^{o}=H$ and that $w_{o}>w_{e}$, the module of religious activity is influenced by the preferences of the household-pastor. In order to maximize its well-being through the consumption of religious, secular and leisure goods, the household-pastor increases the income derived from its religious activity by employing only a large quantity $M$ of faithful in the «house-church» only and free of charge. In addition, he supplements his income by directing a quantity $H$ of working time outside the «house-church», which allows him to receive remuneration $w_{o} H$. The «born again» carry out free religious activities while by making financial contributions $\tau$ in the «house-church».

Result 4 shows that the faithful make contributions and offer free working time in «house-church». In fact, despite the satisfaction they have in serving God, the faithful are constantly tempted to offer their labor power outside the «house-church» in order to be paid to $w_{o}$. For its part, the household-pastor benefits from higher wages $w_{o}$ by offering all of the $H$ hours of work outside the «house-church». The rest of his time is therefore devoted to leisurel.

Among the results presented above, the various media reports (misappropriation of tithes, enrichment of pastors and prophets, complaints from certain faithful exploited in places of worship, etc.) show that result 3 can explain the functioning of several Revival Churches in developing countries, in general, and in Africa, in particular. This result confirms the reflections carried out by Fath and Mayrargue (2014) and Nana Ngassam (2020) on certain African countries, which show the influence of the economic context (unemployment and wage rates) on the behavior of revival churches. Indeed, the Revival churches officiate in a context of unemployment and poverty. They employ as many devotees as possible in religious activities (selling prayer books, lucky charms, t-shirts, success pens, etc. considered to be sources of blessing) and home improvement-church (purchase of water, candles, olive oil, land, building or even materials). The faithful, sometimes unemployed and anxious to serve God (some 24 hours a day), support zero or much lower remuneration than that of the labor market.

\section{Conclusion}

In this article, we have studied the behavior of a revival church from a theoretical model. More precisely, we were inspired by an agricultural household model (MMA) to analyze the behavior of a household that maximizes its satisfaction by consuming religious, secular and leisure goods. For this fact, the household becomes a pastor, and then transforms its house into a church. He allocates his time in order to attract and maintain faithful who, born again, offer their work in religious activity and/or contribute financially. In such an organization, therefore, there is no distinction between housing and the church. The resolu- 
tion of the program by the Lagrangian method highlights four possible results. We show that the behavior of the revival church is determined by the economic context: the level of employability in the competitive job market, on the one hand, and the gap between the salary outside the "house-church» and the internal salary fixed by the household-pastor to remunerate religious activity, on the other hand. In addition, we argue that in Africa, Revival Churches officiate in a context of unemployment and employ the maximum number of faithful in church activities and improvement. In return, they receive a remuneration lower than that of the labor market (case 4).

\section{Acknowledgements}

First of all, I would like to thank the editor and the referee for their comments. My thanks also go to the various members of the International Center for Reflexion in Economics and Management for Development (CIREGED) for the day-to-day discussions. Nonetheless, I am solely responsible for any errors and omissions in this study.

\section{Conflicts of Interest}

The author declares no conflicts of interest regarding the publication of this paper.

\section{References}

Anderson, G. M., \& Tollison, R. D. (1992a). Morality and Monopoly: The Constitutional Political Economy of Religious Rules. Cato Journal, 12, 373-392.

Anderson, G. M., Ekelund, R. B., Hebert, R. F., \& Tollison, R. D. (1992b). An Economic Interpretation of the Medieval Crusades. Journal of European Economic History, 21, 339-363.

Azzi, C., \& Ehrenberg, R. G. (1975). Household Allocation of Time and Church Attendance. Journal of Political Economy, 84, 27-56. https://doi.org/10.1086/260305

Bardhan, P., \& Udry, C. (1995). Development Microeconomics. Oxford: Oxford University Press.

Barros, P. P., \& Garoupaz, N. (2001). An Economic Theory of Church Strictness. Working Paper.

Becker, G. S. (1976). The Economic Approach to Human Behavior. Chicago, IL: University of Chicago Press.

Benjamin, D. (1992). Household Composition, Labor Markets, and Labor Demand: Testing for Separation in Agricultural Household Models. Econometrica, 60, 287-322. https://doi.org/10.2307/2951598

Berger, P. L. (1967). The Sacred Canopy. New York: Random House.

Cassone, A., \& Marchese, C. (1999). The Economics of Religious Indulgences. Journal of Institutional and Theoretical Economics, 152, 429-442.

Davidson, A. B., \& Ekelund, R. B. (1997). The Medieval Church and Rents from Marriage Market Regulations. Journal of Economic Behavior and Organization, 32, 215-245. https://doi.org/10.1016/S0167-2681(96)00903-1 
Ehrenberg, R. G. (1977). Household Allocation of Time and Religiosity: Replication and Extension. Journal of Political Economy, 85, 415-423.

Ekelund, R. B., \& Hebert, R. F. (2009). Interest Groups, Public Choice and the Economics of Religion. Public Choice, 142, 429-436. https://doi.org/10.1007/s11127-009-9543-7

Ekelund, R. B., Hebert, R. F., \& Tollison, R. D. (1989). An Economic Model of the Medieval Church: Usury as a Form of Rent Seeking. Journal of Law, Economics and Organization, 5, 307-331.

Ekelund, R. B., Hebert, R. F., \& Tollison, R. D. (1992). The Economics of Sin and Redemption: Purgatory as a Market-Pull Innovation? Journal of Economic Behavior and Organization, 19, 1-15. https://doi.org/10.1016/0167-2681(92)90067-L

Ekelund, R. B., Hebert, R. F., \& Tollison, R. D. (1996). Sacred Trust: The Medieval Church as an Economic Firm. Oxford: Oxford University Press.

Ekelund, R. B., Hebert, R. F., \& Tollison, R. D. (2002). An Economic Analysis of the Protestant Reformation. Journal of Political Economy, 110, 646-671. https://doi.org/10.1086/339721

Fath, S., \& Mayrargue, C. (2014). Les nouveaux christianismes en Afrique. Introduction thématique. Afrique Contemporaine, 4, 15. https://doi.org/10.3917/afco.252.0013

Finke, R., \& Stark, R. (1988). Religious Economies and Sacred Canopies: Religious Mobilization in American Cities, 1906. American Sociological Review, 53, 41-49. https://doi.org/10.2307/2095731

Finke, R., \& Stark, R. (1992). The Churching of America, 1776-1990: Winners and Losers in Our Religious Economy. New Brunswick, NJ: Rutgers University Press.

Hull, B. B., \& Bold, F. (1989). Towards an Economic Theory of the Church. International Journal of Social Economics, 16, 5-15. https://doi.org/10.1108/EUM0000000000444

Iannaccone, L. R. (1988). A Formal Model of Church and Sect. American Journal of Sociology, 94, s241-s268. https://doi.org/10.1086/228948

Iannaccone, L. R. (1990). Religious Practice: A Human Capital Approach. Journal for the Scientific Study of Religion, 29, 297-314. https://doi.org/10.2307/1386460

Iannaccone, L. R. (1992). "Sacrifice and Stigma: Reducing Free-Riding in Cults, Communes, and Other Collectives," J. Polit. Econ., 100:2, pp. 271-97.

Iannaccone, L. R. (1994a). Why Strict Churches Are Strong. American Journal of Sociology, 99, 1180-1211. https://doi.org/10.1086/230409

Iannaccone, L. R. (1994b). Progress in the Economics of Religion. Journal of Institutional and Theoretical Economics, 150, 737-744.

Iannaccone, L. R. (1995a). Risk, Rationality and Religious Portfolios. Economic Inquiry, 38, 285-295. https://doi.org/10.1111/j.1465-7295.1995.tb01863.x

Iannaccone, L. R. (1995b). Voodoo Economics? Reviewing the Rational Choice Approach to Religion. Journal for the Scientific Study of Religion, 34, 76-88.

https://doi.org/10.2307/1386524

Iannaccone, L. R. (1998). An Introduction to the Economics of Religion. Journal of Economic Literature, 36, 1465-1495.

Iyer, S. (2016). The New Economics of Religion. Journal of Economic Literature, 54, 395-441. https://doi.org/10.1257/jel.54.2.395

Jahoda, M., Lazarsfeld, P. F., \& Zeisel, H. (1971). Marienthal: The Sociography of an Unemployed Community. New York: Aldine-Atherton.

McKee-Ryan, F., Song, Z., Wanberg, C. R., \& Kinicki, A. J. (2005). Psychological and 
Physical Well-Being during Unemployment: A Meta-Analytic Study. The Journal of Applied Psychology, 90, 53-76.

Montgomery, J. D. (1996a). The Dynamics of the Religious Economy: Exit, Voice and Denominational Secularization. Rationality and Society, 8, 83-110. https://doi.org/10.1177/104346396008001004

Montgomery, J. D. (1996b). Contemplations on the Economic Approach of Religious Behavior. American Economic Review, AEA Papers and Proceedings, 86, 443-447.

Nana Ngassam, R. (2020). Cameroun: Les églises de réveil à Douala. International, Fondation Jean Jaurès.

Obadia, L. (2017). Marché, business etconsumérisme en religion: Vers un tournant économique en sciences des religions? Mélanges de l'Écolefrançaise de Rome-Italieet Méditerranéemodernes et contemporaines.

http://journals.openedition.org/mefrim/3475 https://doi.org/10.4000/mefrim.3475

Paul, K. I., \& Moser, K. (2009). Unemployment Impairs Mental Health: Meta-Analyses. Journal of Vocational Behavior, 74, 264-282.

Simmonot, P. (2008). Le marché de Dieu. L'économie des religions monothéistes. Paris.

Singh, I., Squire, L., \& Strauss, J. (1986). Agricultural Household Models: Extensions, Application and Policy. Baltimore, MD: Johns Hopkins University Press.

Soiron Fallut, M. (2012). Les églises de réveil en Afriquecentraleetleurs impacts surl'équilibre du pouvoir et la stabilitédes Etats: Les cas du Cameroun, du Gabon et de la République du Congo. Ministère de la Défense-Délégation aux Affaires Stratégiques.

Stark, R., \& Bainbridge, W. S. (1985). The Future of Religion. Berkeley, CA: University of California Press.

Stark, R., \& Bainbridge, W. S. (1987). A Theory of Religion. Bern: Peter Lang.

Stark, R., Iannaccone, L. R., \& Finke, R. (1996). Religion, Science, and Rationality. American Economic Review, 86, 433-437.

Sullivan, D. H. (1985). Simultaneous Determination of Church Contributions and Church Attendance. Economic Inquiry, 23, 309-320. https://doi.org/10.1111/j.1465-7295.1985.tb01767.x

Zdeski, R. P., \& Zech, Ch. E. (1992). Determinants of Contributions to Religious Organizations: Free-Riding and Other Factors. American Journal of Economics and Sociology, 51, 459-472. https://doi.org/10.1111/j.1536-7150.1992.tb02729.x 


\section{Appendices}

1). Demonstration of Equation (11).

Using the first two identities, the constraint (10). becomes:

$$
\begin{gathered}
p_{c} c+p_{k} k=\tau q-w_{e} \alpha L^{b}+w_{o} L^{o}+y \\
p_{c} c+p_{k} k=\tau F\left(L_{e}^{f} ; A\right)-w_{e} \alpha L^{b}+w_{o} L^{o}+y
\end{gathered}
$$

By integrating the time allocation of the household-pastor, it is written as follows:

$$
\begin{gathered}
p_{c} c+p_{k} k=\tau F\left(L_{e}^{f} ; A\right)-w_{e} \alpha L^{b}+w_{o}\left(T(\theta)-L^{f}-l\right)+y \\
p_{c} c+p_{k} k=\tau F\left(L_{e}^{f} ; A\right)-w_{e} \alpha L^{b}+w_{o} T(\theta)-w_{o} L^{f}-w_{o} l+y \\
p_{c} c+p_{k} k+w_{o} l=\tau F\left(L_{e}^{f} ; A\right)-w_{e} \alpha L^{b}+w_{o} T(\theta)-w_{o} L^{f}+y \\
p_{c} c+p_{k} k+w_{o} l=\tau F\left(L_{e}^{f} ; A\right)-w_{o}\left[L^{f}+\left(w_{e} / w_{o}\right) \alpha L^{b}\right]+w_{o} T(\theta)+y
\end{gathered}
$$

To simplify, we propose the following profit relation:

$$
\psi\left(L_{e}^{f} ; A ; w_{o} ; w_{e} ; L^{f} ; L^{b} ; \tau ; \alpha\right)=\tau F\left(L_{e}^{f} ; A\right)-w_{o}\left[L^{f}+\left(w_{e} / w_{o}\right) \alpha L^{b}\right]
$$

We write the constraints as follows:

$$
p_{c} c+p_{k} k+w_{o} l=\psi\left(L_{e}^{f} ; A ; w_{o} ; w_{e} ; L^{f} ; L^{b} ; \tau ; \alpha\right)+w_{o} T(\theta)+y \equiv R
$$

2). Demonstration of the relation (14).

Alternative 1: $w_{o}=w_{e}$

$$
\psi\left(L_{e}^{f} ; A ; w_{o} ; w_{e} ; L^{f} ; L^{b} ; \tau ; \alpha\right)=\tau F\left(L_{e}^{f} ; A\right)-w_{o}\left[L^{f}+\alpha L^{b}\right]
$$

Or, $L_{e}^{f}=L^{f}+\alpha L^{b}$

We obtain:

$$
\psi\left(L_{e}^{f} ; A ; w_{o} ; w_{e} ; L^{f} ; L^{b} ; \tau ; \alpha\right)=\tau F\left(L_{e}^{f} ; A\right)-w_{o} L_{e}^{f}
$$

3). Demonstration of the relation (36).

Case 2: $L^{o}=H$

We can write:

$$
T(\theta)=L^{f}+H+l \text { Or, } L^{f}=T(\theta)-H-l
$$

With, $L_{e}^{f}=L^{f}+\alpha L^{b}$. We obtain: $L_{e}^{f}=T(\theta)-H-l+\alpha L^{b}$ As the household-pastor constraint is:

$$
p_{c} c+p_{k} k=\tau F\left(L_{e}^{f} ; A\right)-w_{e} \alpha L^{b}+w_{o} L^{o}+y
$$

She becomes:

$$
p_{c} c+p_{k} k=\tau F\left(T(\theta)+\alpha L^{b}-H-l ; A\right)-w_{e} \alpha L^{b}+w_{o} H+y
$$

4). Demonstration of the relation (47).

We know that:

$$
p_{c} c+p_{k} k=\tau F\left(L_{e}^{f} ; A\right)-w_{e} \alpha L^{b}+w_{o} L^{o}+y
$$


Now, as knows that: $L^{o}=H$, we can write: $L_{e}^{f}=T(\theta)-H-l+\alpha L^{b}$, which give:

$$
p_{c} c+p_{k} k=\tau F\left(T(\theta)+\alpha L^{b}-H-l ; A\right)-w_{e} \alpha L^{b}+w_{o} H+y
$$

By factorizing the second component of the left term of equality by $w_{o}$, we have:

$$
p_{c} c+p_{k} k=\tau F\left(T(\theta)+\alpha L^{b}-H-l ; A\right)+w_{o}\left[H+\left(w_{e} / w_{o}\right) \alpha L^{b}\right]+y \equiv R
$$

